Arab Univ. J. Agric. Sci., Ain Shams Univ., Cairo, 14(2), 823-833, 2006

\title{
CROSS RESISTANCE OF DIPEL 2x RESISTANT STRAIN OF PINK BOLLWORM PECTINOPHORA GOSSYPIELLA (SAUND.) TO SOME CONVENTIONAL AND BIOINSECTICIDES
}

\section{[53]}

El-Zemaity, M.S. ${ }^{1}$; A.E. Bayoumi ${ }^{1}$; Mona F. Rofail ${ }^{2}$ and Hemat Z. Moustafa ${ }^{2}$

\begin{abstract}
A field strain of pink bollworm Pectinophora gossypiella (Saund.) collected from Sharquia Governorate, Egypt was exposed to the selection pressure of the formulation of Bacillus thuringiensis subsp. Kurstaki, Dipel 2x under laboratory conditions. Resistance ratio attained 16-fold based on the susceptible strain after 14 generations of selection. Study the response of Dipel 2x resistant strain to some insecticides indicated that there is no cross resistance to the conventional insecticides, esfenvalerate, chlorpyriphos and thiodicarb or the bioinsecticides Ecotech and Agerin. These data may be emphasizing the possibility of rotation the Dipel $2 \mathrm{x}$ with these insecticides in pest control program of pink bollworm to manage resistance to $\mathrm{Bt}$ products.
\end{abstract}

Keywords: Pink bollworm, Selection, Cross resistance, Bacillus thuringiensis, Dipel 2x

\section{INTRODUCTION}

Pink bollworm Pectinophora gossypiella (Saund.) is one of the most serious pest attacking cotton crop in Egypt as well as the most cotton producing countries which cause a great damage in the quality and quantity of cotton yield (ElNaggar, 2003). Since several decades, the extensive usage of the conventional pesticides to control such insect pest, caused the development of resistance against different compounds which belongs to various chemical groups. To solve this problem, it was substituted such traditional pesticides with the biopesticides based on microorganisms such as bacterial species which producing a specific toxins capable to kill the insect pests. Actually, Bacillus thuringiensis $(B t)$ as a biopesticide is a valuable source of insecticidal proteins for use in conventional sprayable formulations, in transgenic crops and it is the most promising alternative to synthetic insecticides (Ferré and Van Rie, 2002). The benefits of using $B$. thuringiensis on cotton crops include reduced environmental and worker exposure to conventional insecticides, reduced selection for resistance to con-

1- Plant Protection Department, Faculty of Agriculture, Ain Shams University, Shoubra El-Kheima, Cairo, Egypt.

2- Plant Protection Research Institute, Agricultural Research Center, Dokki, Giza, Egypt 
ventional insecticides and improved conservation of natural enemies. However Lepidopteran insect resistance to Bt., has been known since 1985 but only in a few taxonomic families. Nonetheless, these insects were susceptible to other $B t$ toxins. Resistance to $B$. thuringiensis has documented for several insect species (Tabashnik, 1994). Pink bollworm and more than a dozen other pests have been selected in the laboratory for resistance to B. thuringiensis toxin (Frutos et al 1999). Since the resistance of such pests is expected, the aim of the present work is to investigate the development of resistance of $P$. gossypiella to a formulation of B. thuringiensis Dipel $2 \mathrm{x}$. Crossresistance of the resistant strain to conventional insecticides (esfenvalerate, chlorpyrifos \& thiodicarb) and bioinsecticides (ecotech \& agerin) was also studied.

\section{MATERIAL AND METHODS}

\section{Bioassay and selection pressure proce- dures for resistance}

Newly hatched larvae of a susceptible strain of $P$. gossypiella (Saund.) were obtained from the Bollworm Research Division, Plant Protection Research Institute, ARC, Dokki, Giza, Egypt. Larvae were reared on semi-artificial diet under laboratory conditions for several generations away from exposure to any insecticidal pressure according to the method described by Rashad and Ammar (1984). Field strain (parents) was collected from Ebrahemia region, Sharquia Governorate, Egypt during 2002-2003 cotton season and reared under laboratory conditions as the same with susceptible strain.
Response of the newly hatched larvae of the two strains to Dipel $2 \mathrm{x}$ were studied. Serial dilutions of the agent ranged from 10 to $1000 \mathrm{ppm}$ were prepared in distilled water. Each concentration was mixed with $50 \mathrm{~g}$ of the artificial diet with the exclusive of antibacterial ingredient. This treated diet was divided into four petri dishes (9 $\mathrm{cm}$ diameter). Ten newly hatched larvae were transferred to the surface of diet on each petri dish. Control dishes were mixed only with distilled water. All dishes were incubated at $27 \pm$ $0.5{ }^{\circ} \mathrm{C}$ and $70-85 \%$ R.H. Two days later, dead larvae were counted and removed. The alive larvae were transferred individually to glass tubes $(2 \times 7.5 \mathrm{~cm})$ containing untreated diet. Selection for resistance was carried out using concentration corresponding to the estimated $\mathrm{LC}_{50}$ value every generation by treated the newly hatched larvae.

According to the response of the treated larvae to selection, higher concentrations of Dipel 2x were used in subsequent generation. Mortality was recorded 5, 7, 10 days post treatment. Accumulative percentage mortalities were calculated and corrected according to the formula described by Abbott (1925). From the corrected mortality percent and the concentrations used, it was plotted the toxicity regression lines of the tested compound and represented in Log/probit relation according to the method of Finney, (1972) using the computer program, Sigma Plot for Windows, Version 2.0. $\mathrm{LC}_{50}$ and slope values were estimated for S-strain, parent (Field strain), $1^{\text {st }}, 3^{\text {rd }}, 7^{\text {th }}$, $10^{\text {th }}, 12^{\text {th }}$ and $14^{\text {th }}$ generation. Development of resistance ratio as well as relative resistibility for each generation were calculated as follows: 
Resistant ratio $=\mathrm{LC}_{50}$ of the selected strain / $\mathrm{LC}_{50}$ of susceptible strain.

Relative resistibility $=\mathrm{LC}_{50}$ of selected generation / $\mathrm{LC}_{50}$ of anterior generation.

\section{Cross resistance of Dipel $2 x$ resistant strain to the tested insecticides}

The resistant strain as well as the susceptible strain were exposed to three chemical insecticides representing the major groups of insecticides, i.e. esfenvalerate (Sumialfa) as a pyrethroid compound, chlorpyriphos (Dursban) as organophosphorous and thiodicarb (Larvin) as carbamate and two bioinsecticides Ecotech and Agerin. Newly hatched larvae of each strain was exposed to serial dilutions of the tested insecticides as mentioned before. The corrected mortality percentages were estimated and the $\mathrm{LC}_{50}$ values were evaluated according to Finney, (1972). The resistance ratio of the tested insecticides $\left(\mathrm{LC}_{50}\right.$ value of $\mathrm{R}$-strain / $\mathrm{LC}_{50}$ value of $\mathrm{S}$-strain) was calculated and the differences of 5-fold or more were considered as indicating positive correlation while those between 1: 4-fold were considered as indicating to no correlation. Differences less than 1-fold represented a probable negative correlation.

\section{Statistical Analysis}

All of the toxicity values ( $\mathrm{LC}_{50}$ 's) which estimated from the plotted toxicity regression lines and their corresponding slope values were calculated using the Probit Analysis Program designed by Dr. Nabil AM. Abd EL-Salam, Plant Protection Institute, Dokki, Giza, Egypt. The significant differences between the mentioned values were statistically analyzed using the Computer program Statitica for Windows, version 4.5.

\section{RESULTS AND DICUSSION}

\section{Developed of resistance of pink boll- worm to biopesticide Dipel $2 x$}

$\mathrm{LC}_{50}$ values of Dipel 2x (B. thuringiensis subspecies Kurstaki) to the different strains of $P$. gossypiella (Saund.) during 14 generations of selection pressure were presented in Table (1) while the plotted toxicity regression lines were illustrated in Figure (1). The estimated $\mathrm{LC}_{50}$ values clearly indicate a gradual increase during the tested generations from 200 $\mathrm{ppm}$ in $1^{\text {st }}$ generation to $1280 \mathrm{ppm}$ in $14^{\text {th }}$ generation. In this respect, Simmons et al (1998) reported that the field populations of pink bollworm $P$. gossypiella were more susceptible to the endotoxin CryIAc than the susceptible laboratory strain. Regarding the resistance ratio data show a level of 2.5 and 2.63-fold in G1 and G2, respectively. Then reached a level of tolerance during the $3^{\text {rd }}$ generation (4.13fold). With further selection, the resistance ratio show resistance level during G7 (5.63-fold). The resistance ratios increased again to $7.25,11.25,12.37$ and 16-fold during generations 10, 11, 12 and 14 , respectively. The slope values were nearly close to each other and remained nearly similar till the end of selection.

Similar findings were also indicated by Tabashnik et al $(1990$ \& 1995) when they studied the resistance phenomenon in field population of diamondback moth Plutella xylostella (L.). In their studies, they showed that repeated selection with high concentrations of commercial formulation of B. thuringiensis subsp. Kurstaki caused development of resistance. 
Table 1. Development of resistance rates to Dipel 2x in P. gossypiella (Saund.) during selection for 14 generations.

\begin{tabular}{|ccccc|}
\hline $\begin{array}{c}\text { Selection } \\
\text { generations }\end{array}$ & $\begin{array}{c}\mathrm{LC}_{50}(\mathrm{ppm}) \\
\text { (5\% fiducial limits) }\end{array}$ & Slope & $\begin{array}{c}\text { Resistance } \\
\text { Ratio } \\
\text { (Fold) }\end{array}$ & $\begin{array}{c}\text { Relative Resis- } \\
\text { tibility }\end{array}$ \\
\hline $\begin{array}{c}\text { Susceptible } \\
\text { Parent }\end{array}$ & $\begin{array}{c}\text { 70.0 (50.0-100.0) } \\
\text { G1 }\end{array}$ & 1.38 & - & - \\
G2 & $200.0(150.0-90.0)$ & 1.20 & 0.88 & - \\
G3 & $300.0(150.0-270.0)$ & 1.59 & 2.50 & 2.85 \\
G7 & $450.0^{*}(330.0-620.0)$ & 1.31 & 5.63 & 1.00 \\
G10 & $580.0^{* *}(430.0-790.0)$ & 1.42 & 7.25 & 1.65 \\
G11 & $900.0^{* *}(680.0-1190.0)$ & 1.74 & 11.25 & 1.36 \\
G12 & $990.0^{* *}(690.0-1410.0)$ & 1.13 & 12.37 & 1.55 \\
G14 & $1280.0^{* *}(840.0-1950.0)$ & 0.98 & 16 & 1.71 \\
\hline
\end{tabular}

Comparing to the parent generation, $(* * *)$ highly significant $\left.p \leq 0.001,{ }^{* *}\right)$ moderately significant $p \leq 0.01$

and $(*)$ significant $p \leq 0.05$ (student $t$-test).

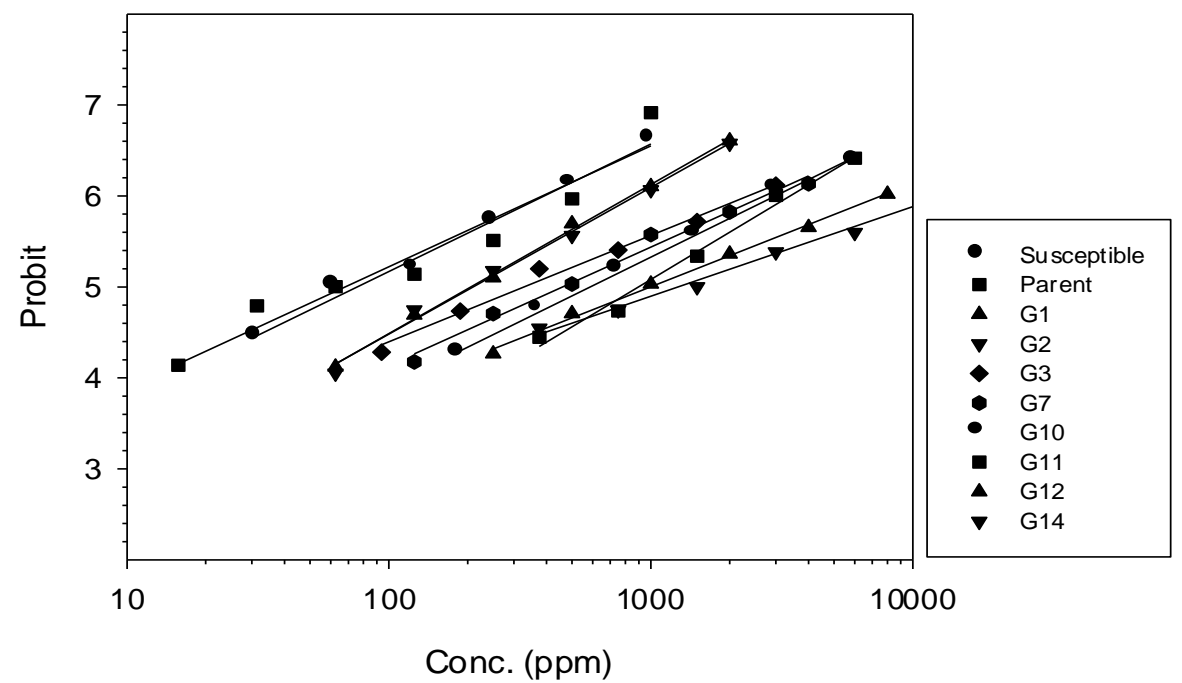

Fig. 1. Toxicity regression lines of Dipel-2x against the tested generations of P. gossypiella. 
Also, Gould et al (1995) reported that selection of field collected strain of Heliothis virescens on artificial diet containing CryIA(c) developed only moderate resistance ( 7 to 8 - fold) after 12 episodes of selection.

However, it is well documented that the further selection lead to higher levels of resistance. In this respect, Bolin et al (1999), and Huang et al (1999) reported that European corn borer Ostrinia nubilalis developed resistance to $B$. thuringiensis after 8 generations of selection. Recently, Hussein (2002) and Sabry (2002) stated that selection with Dipel $2 x$ produced 16.32-fold after 10 generations of selection in Spodoptera littoralis and 14.8-fold after 11 generations of selection of $P$. gossypiella. Also, it was reported that laboratory selection increased resistance of pink bollworm $P$. gossypiella to the $B$. thuringiensis in artificial diet from a low level to $>100$-fold relative to a susceptible strain (Patin et al 1999; Liu et al 2001 and Tabashnik et al 2002). More recently, it was found that the obtained results are in agreement with that obtained by (El-Zemaity et al 2003 \& 2004) which were studied the development of resistance and the response of $B t$ resistant strain of Spodoptera littoralis to certain conventional insecticides and bioinsecticides.

\section{Cross resistance to certain insecticides}

The estimated $\mathrm{LC}_{50}$ values of the tested insecticides on susceptible and Dipel 2x resistant strain of $P$. gossypiella are listed in Table (2) while the corresponding toxicity regression lines are illustrated in Figures (2-6). According to such values, it was found that the resistance ratios reached to $1.71,1.4$ and 1.29 - fold to esfenvalerate, chlorpyrifos and thiodicarb, respectively. These results indicate no cross resistance between these conventional insecticides and Dipel $2 \mathrm{x}$ resistant strain. The same finding were recorded with Ecotech and Agerin, where resistance ratios revealed 1.24 and 1.51fold, respectively (Figs.5-6). These data may be emphasize the possibility of rotation Dipel $2 \mathrm{x}$ with these insecticides in pest control program of cotton bollworm to manage resistance to $B t$ products.

Due to the different mode of action between $B$. thuringiensis and the conventional insecticides, Whalon et al (1993) reported that no cross resistance could be observed between organophosphate, carbamate, or pyrethroid resistance and B.thuringiensis resistant strain of Colorado potato beetle Leptinotarsa decemlineata (Say). Also, Hussein (2002) showed that no cross resistance could be recorded in Spodoptera littoralis between tested bioagents and the chemical insecticides. In the same way, Wu and Guo (2004) observed no positive cross resistance between Cry1Ac toxin and conventional insecticides lambda, cyhalothrin, phoxim and endosulfan and the level of the resistance to these insecticides gradually came down to a level similar to that of the susceptible strain of Helicoverpa armigera. Considering cross resistance between bioinsecticides, Gould $\boldsymbol{e t}$ al (1995) and Akhurst et al (2003) found that a strain of Helicoverpa armigera and Heliothis virescens selected with CryIAc was not resistant to the commercial $B t$ spray formulations Dipel 2x and Xentari. In the contrary, it was found that the selected colonies of European corn borer Ostrinia nubilalis (Hubner) with B.thuringiensis CryIAc toxin was 
Table 2. Response of Dipel 2x resistant strain of P. gossypiella (Saund.) to the tested compounds.

\begin{tabular}{|cccccc|}
\hline \multirow{2}{*}{$\begin{array}{c}\text { Tested insecti- } \\
\text { cides }\end{array}$} & $\begin{array}{c}\mathrm{LC}_{50}(\mathrm{ppm}) \\
\text { (Fiducial limits) }\end{array}$ & Slope & $\begin{array}{c}\mathrm{LC}_{50}(\mathrm{ppm}) \\
\text { (Fiducial limits) }\end{array}$ & Slope & $\begin{array}{c}\text { Resistance } \\
\text { ratio }\end{array}$ \\
\hline Esfenvalerate & $0.14(0.09-0.20)$ & 1.19 & $0.24(0.16-0.37)$ & 1.14 & 1.71 \\
Chlorpyrifos & $0.03(0.04-0.07)$ & 1.47 & $0.07(0.05-0.11)$ & 1.05 & 1.4 \\
Thiodicarb & $70.80(53.22-94.18)$ & 1.88 & $91.36(63.31-131.86)$ & 1.30 & 1.29 \\
Ecotech & $380(280-500)$ & 1.41 & $470(350-630)$ & 1.53 & 1.24 \\
Agerin & $350(240-510)$ & 1.12 & $530(390-730)$ & 1.45 & 1.51 \\
\hline
\end{tabular}

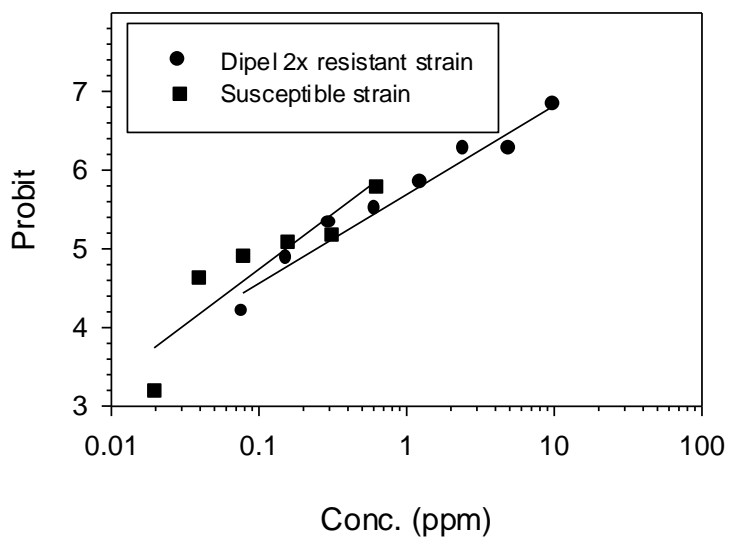

Fig. 2. Toxicity regression lines of esfenvalerate against susceptible and Dipel 2x resistant strain of $P$. gossypiella. 


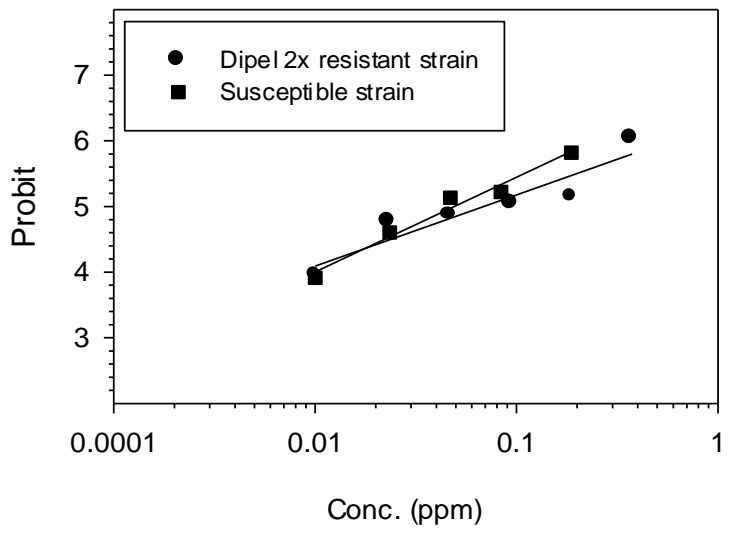

Fig. 3. Toxicity regression lines of chlorpyrifos against susceptible and Dipel 2x resistant strain of $P$. gossypiella.

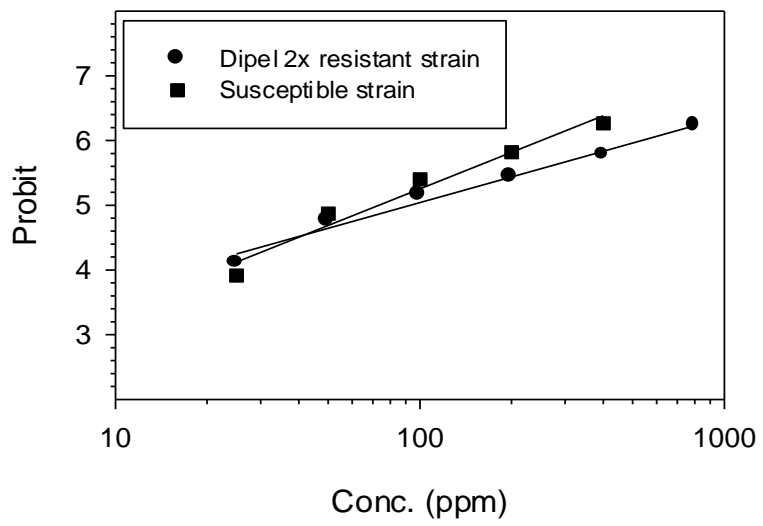

Fig. 4. Toxicity regression lines of thiocarb against susceptible and Dipel $2 x$ resistant strain of $P$. gossypiella.

Arab Univ. J. Agric. Sci., 14(2), 2006 


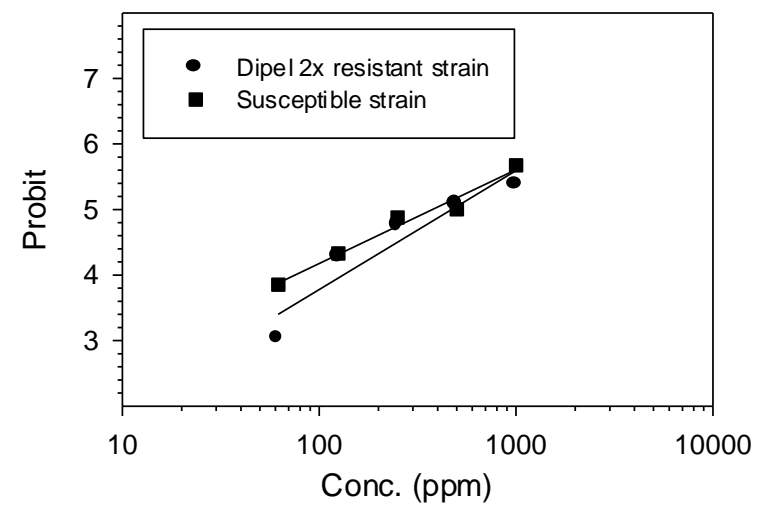

Fig. 5. Toxicity regression lines of Ecotech against susceptible and Dipel $2 x$ resistant strain of $P$. gossypiella.

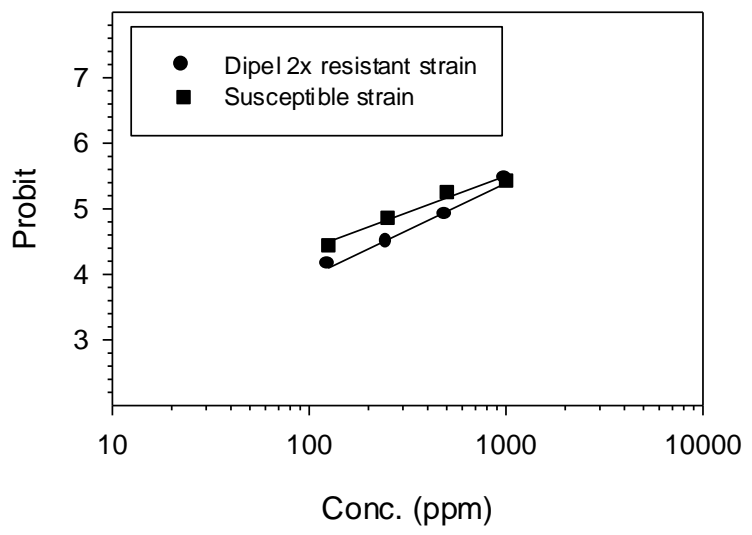

Fig. 6. Toxicity regression lines of Agerin against susceptible and Dipel $2 x$ resistant strain of $P$. gossypiella. 
marginally cross resistant to CryIab (Bolin et al 1999).

\section{REFERENCES}

Abbott, W.S. (1925). A method of computing the effectiveness of an insecticide. J. Econ. Entomol. 18: 265-267.

Akhurst, R.J.; W. James; L.J. Bird and C. Beard (2003). Resistance to the Cry1Ac $\delta$-Endotoxin of Bacillus thuringiensis in the cotton bollworm Helicoverpa armigera (Lepidoptera: Noctuidae). $\boldsymbol{J}$. Econ. Entomol. 96(4): 1290-1299.

Bolin, P.C.; W.D. Hutchison and D.A. Andow (1999). Long-term selection for resistance to Bacillus thuringiensis Cry1Ac endotoxin in a Minnesota population of European corn borer. (Lepidoptera: Crambidae). J. Econ. Entomol. 92(5): 1021-1030.

El-Naggar, A.Z.A. (2003). Evaluation of Certain New Approaches of Control Measures in an Integrated Pest Management Program of Cotton Bollworms. p. 1. Ph.D. Thesis. Fac. Agric. Alexandria University, Egypt.

El-Zemaity, M.S.; W.M. El-Deeb; Y.A. Osman and A.I. Hussien (2003). Development of resistance of Spodoptera littoralis to certain bioinsecticides. J. Environ. Sci. 6(3): 793-810.

El-Zemaity, M.S.; W.M. El-Deeb; Y.A. Osman and A.I. Hussien (2004). Response of $B t$ resistant strains of cotton leafworm to some chemical insecticides. $X V^{\text {th }}$ International Plant Protection Congress, Beijing, China, May 11-16, 2004.

Ferré, J. and J. Van Rie (2002). Biochemistry and Genetics of insect resistance to Bacillus thuringiensis. Annu. Rev. Entomol. 47: 501-533.

Finney, D.J. (1972). Probit Analysis: a
Statistical Treatment of the Sigmoid Response Curve. p. 33. Cambridge Univ. Press, London.

Frutos, R.; C. Rang and M. Royer (1999). Managing insect resistance to plants producing Bacillus thuringiensis toxins. Crit. Rev. Biotechnol. 19: 227276.

Gould, F.; A. Anderson; A. Reynolds; L. Bumgarner and W. Moar (1995). Selection and genetic analysis of a Heliothis virescens (Lepidoptera:Noctuidae) strain with high levels of resistance to Bacillus thuringiensis toxins. J. Econ. Entomol., 88(6): 1545-1559.

Huang, F.; R.A. Higgins and L.L. Buschman (1999). Heritability and stability of resistance to Bacillus thuringiensis in Ostrinia nubilalis (Lepidoptera: Pyralidae). J. Econ. Entomol. 89: 449. 454.

Hussein, A.I. (2002). Development of Response of Spodoptera littoralis to Certain Environmental Biopesticides. p. 96. M.Sc. Thesis, Institute of Environmental Studies \& Research, Ain Shams Univ., Egypt.

Liu, Y.B.; B.E. Tabashnik; S.K. Meyer; Y. Carriere and A.C. Bartlett (2001). Genetics of pink Bollworm Resistance to Bacillus thuringiensis Toxin Cry1Ac. J. Econ. Entomol. 94(1): 248-252.

Patin, A.L.; T.J. Dennehy; M.A. Sims; B.E. Tabashnik; Y.B. Liu; L. Antilla; D. Gouge; T.J. Henneberry and R. Staten (1999). Status of pink bollworm susceptibility to $B t$ in Arizona. Proceedings Beltwide Cotton Conferences, Orlando, Florida, USA, 3-7, January(2): 991-996. Rashad, A. and E. D. Ammar (1984). Mass rearing of the spiny bollworm $E a$ rias insulana (Boisd.) on semi artificial diet. Bull. Entomol. Soc. Egypt 65: 239 244. 
Sabry, K. H. (2002). Resistance of Pink Bollworm Pectinophora gossypiella (Saunders) to the Microbial Insecticide Bacillus thuringiensis. p.79. M. Sc. Thesis, Fac. Agric. Zagazig University, Egypt.

Simmons, A.L.; T.J. Dennehy; B.E. Tabashnik; L. Antilla; A. Bartlett; D. Gouge and R. Staten (1998). Evaluation of B.t. cotton deployment strategies and efficacy against pink bollworm in Arizona. Proceedings Beltwide Cotton Conference. 2: 1025-1030.

Tabashnik, B.E. (1994) Evolution of resistance to Bacillus thuringiensis. Ann. Rev. Entomol. 39: 47-79.

Tabashnik, B.E.; N.L. Cushing; N. Finson and M.W. Johnson (1990). Field development of resistance to Bacillus thuringiensis in diamondback moth (Lepidoptera: Plutellidae). J. Econ. Entomol. 83(5): 1671-1676.

Tabashnik, B.E.; N. Finson; M.W.
Johnson and D.G. Heckel (1995). Prolonged selection affects stability of resistance to Bacillus thuringiensis in diamondback moth (Lepidoptera: Plutellidae). J. Econ. Entomol. 88 (2): 219 224.

Tabashnik, B.E.; Y.B. Liu; T.J. Dennehy; M.A. Sims; M.S. Sisterson; R.W. Biggs and Y. Carriere (2002). Inheritance of Resistance to Bt Toxin CrylAc in a Field-Derived Strain of Pink Bollworm (Lepidoptera: Gelechiidae). J. Econ. Entomol. 95(5): 1018-1026.

Whalon, M.E.; D.L. Miller; R.M. Hollingworth; E.J. Grafius and J.R. Miller (1993). Selection of a Colorado Potato Beetle (Coleoptera:Chrysomelidae) strain resistant to Bacillus thuringiensis. J. Econ. Entomol. 86(2): 226-233.

Wu, K. and Y. Guo (2004). Changes in susceptibility to conventional insecticides of a Cry1Ac-selected population of Helicoverpa armigera (Hubner) (Lepidoptera: Noctuidaae.). Pest. Manag. Sci. 60: 680684. 
بحلة اتحاد الجامعات العربية للدراسات والبحوث الزراعية، جامعة عين شمس، القاهرة، 14(2)، 823-833، 2006

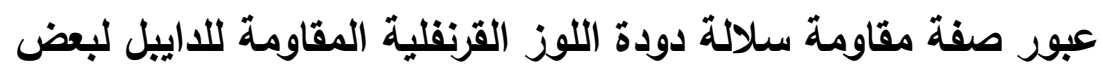
المبيدات الحشرية المعتادة والحيوية

[53]

محمد السعيد صالح الزميتي ${ }^{1}$ - علاء الدين بيومي '- مونا فكرى روفائيل همت زكريا محمد مصطفى 2

1 - قسم وقاية النبات، كلية الزراعة، جامعة عين شمس، شبرا الخيمة، القاهرة، مصر.

2- معهد بحوث وقاية النباتات، مركز البحوث الزراعية، الدقي، الجيزة، مصر.

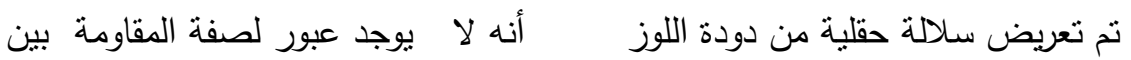

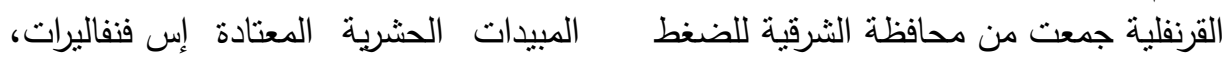
الإنتخابي لمستحضر بكتيريا باسيلس لوربيريفوس، ثيوديكارب أو المبيدات الحيوية ثورنجينسيس (الداييل) تحت ظروف معملية. إكوتيك و أجرين.

وصل مستوي المقاومة 16 ضعفا بعد 14 و 14 وتؤكد هذه النتائج علي إمكانية مناوبة جيلا من الضغط الانتخابي مقارنة بالسلالة الداييل بهذه المبيدات في برنامج مكافحة دودة الحساسة. وأظهرت دراسة إستجابة سلالة اللوز القرنفلية لإدارة مقاومة مستحضرات

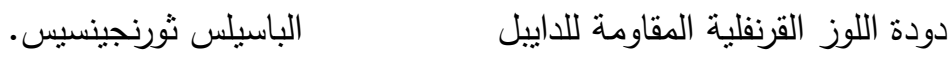

تحكيم: ا.د محمد إيراهيم حسين

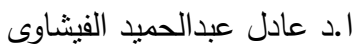

